\title{
RADIONIČARSKI RAD U NASTAVI U KONTEKSTU PODSTICANJA EMPATIJE
}

\author{
Dragana Dimitrijević ${ }^{1}$ \\ Univerzitet u Nišu, Filozofski fakultet, Departman za pedagogiju (Student DAS)
}

\begin{abstract}
Apstrakt: Nastava kao interakcijski proces, u kome se prepliću obrazovni, funkcionalni i vaspitni zadaci, objedinjuje intelektualni, emocionalni i delatni aspekt razvoja ličnosti. Orjentisana ka ovom konceptu, nastava mora pružiti mogućnost učenicima da kroz organizacione aktivnosti razvijaju i mnoštvo emocionalnih komponenti među kojima značajno mesto ima empatija. Kao sposobnost poštovanja, razumevanja i doživljavanja osećaja drugih, empatija se u nastavi može razvijati onim oblicima nastavnog rada koji se zasnivaju na saradničkom odnosu i punom angažovanju učenika u procesu sticanja znanja i razmene iskustava. Kako je pedagoška radionica inovativni oblik nastavnog rada koji se upravo temelji na ovim odlikama, rad ima za cilj da pregledom dosadašnjih istraživanja u ovoj oblasti ukaže na njenu ulogu, mogućnosti i značaj u procesu razvoja empatija kod učenika. Kao osnovni zaključci mogu se izdvojiti: primena saradničkih aktivnosti ostvaruje pozitivne efekte na emocionalni razvoj učenika i podstiče empatiju; aktivnost svih učesnika i zasnovanost na ličnom iskustvu pretpostavlja pozitivnije rezultate na emocionalni razvoj učenika; kreiranje okolnosti da učenici osete različite emocije, igre uloga i simulacije, korišćenje dramskih sadržaja su izdvojene kao najefikasnije aktivnosti u nastavi. Radionica daje mogućnost kombinovanja različitih aktivnosti, te je prepoznata kao najveći potencijal koji nastavnici mogu iskoristiti u svojoj praksi kako bi istakli emocionalni aspekt nastave i doprineli razvoju empatije kod učenika.
\end{abstract}

Ključne reči: socioemocionano učenje, emocionalno vaspitanje, radioničarski rad, nastavni proces.

\section{Uvod}

Empatija u najopštijem smislu podrazumeva posredno sagledavanje emocija i iskustva druge osobe. Iako se ovakvim opštim određenjem na najednostavniji način iskazuje njena suština, ona ipak podrazumeva značajan nivo kompleksnosti koji potiče iz njenog interakcijskog odnosa između afektivnosti i kognicije. Empatija se može posmatrati kao kognitivna svesnost unutrašnjih stanja, misli, percepcija,

\footnotetext{
${ }^{1}$ dimitrijevic.d.93@gmail.com

Stipendista Ministarstva prosvete, nauke i tehnološkog razvoja Republike Srbije.
} 
namera, osećanja druge osobe i kao afektivni odgovor na njih (Hoffman, 1984). Ovo su ujedno i dva pravca u shvatanju i definisanju empatije koji se razlikuju u tome da li naglasak stavljaju na ulogu kognicije ili ulogu emocije u empatičnom doživljaju. Sa druge strane, empatija se, uvažavajući Golemanov model (Goleman, 2007) može posmatrati i kao jedna od pet dimenzija emocionalne inteligencije koju karakterišu sledeće kompetencije: razumevanje drugih, razvijanje drugih, uslužna orijentacija, prednost različitostima i politička svesnost.

Iako je empatija kao psihološki proces i aspekt emocionalne inteligencije predmet interesovanja psihologa, poslednjih godina privlači sve više pažnje pedagoške stručne javnosti i sve više istraživača se bavi mogućnostima vaspitnog delovanja porodice i škole u cilju podsticanja empatičnog doživljaja i razvoja emocionalnih kompetencija dece. Polazna osnova ovog rada jeste nezavidan nivo proučavanja u oblasti vaspitnog, odnosno emocionalnog aspekta nastave. Iz tog razloga osnovno istraživačko pitanje jeste pitanje mogućnosti radioničarkog rada u unapređivanju vaspitnog delovanja nastave i to sa aspekta razvoja empatije kod učenika osnovoškolskog uzrasta. Nakon teorijskog sagledavanja pojma empatije, u radu je dat prikaz različitih istraživanja sa osvrtom na mogućnosti vaspitnog delovanja nastave u kontekstu podsticanja razvoja empatije kod učenika.

\section{Empatija - pojmovno određenje i definisanje}

Pojam empatija (empathy) prvi put se pominje 1909. godine u delima Titera (Titchener), potiče od nemačke reči „Einfuhlung“ i u svom originalnom značenju predstavlja tendenciju posmatrača da projektuje sebe u ono što posmatra. Verovalo se da je unutrašnja imitacija osnovni mehanizam pojave empatije. Ranije su za objašnjenje sličnih psiholoških procesa korišćeni drugačiji termini, kao što je pojam simpatija (eng. simpathy) koji ima svoje korene u 18. veku u radovima Smita (Smith) i Spensera (Spencer). Simpatija u prvobitnom značenju predstavlja način na koji posmatrač oseća ili doživljava drugu osobu za razliku od koncepta empatije koji podrazumeva aktivniji koncept i uživljavanje u emocionalno stanje druge osobe (Davis, 1996).

Termin empatija je tokom istorije različito definisan i proučavan. Sa afektivnog aspekta, empatija se definiše kao povećana reakcija na emocionalno iskustvo drugih ljudi (Mehrabian \& Epstein, 1972). Istraživači su tokom istorije posmatrali empatiju i sa kognitivnog aspekta, koji podrazumeva intelektualni proces percepcije drugih osoba (Hogan, 1975). U novije vreme se uvažava i kognitivni i afektivni aspekt i empatija se posmatra kao skup elemenata koji obuhvataju sve aspekte osetljivosti za druge (Davis, 1996). Multidimenzionalni pristup empatiji koji objedinjuje sve aspekte pomenutih teorijskih polazišta podrazumeva zauzimanje perspektive drugih (eng. perspective taking), fantaziju, empatičnu brigu (eng. empathic concern) i ličnu uznemirenost (eng. personal distress) (Davis, 1983).

Korišćenje termina empatija za objašnjenje različitih fenomena predstavlja pokušaj istraživača da empatijom odgovore na dva pitanja: Kako možemo znati šta 
druga osoba misli i oseća? i Šta navodi osobu da odgovori osetljivo i pažljivo na patnju druge osobe? Za odgovor na prvo pitanje više su se interesovali razvojni psiholozi, filozofi, kognitivni naučnici koji su zainteresovani za teoriju uma i simulacije. Drugo pitanje je polje interesovanja razvojnih i socijalnih psihologa koji imaju cilj da razumeju i promovišu prosocijalno delovanje kroz objašnjenja akcije na koju navodi empatija (Batson, 2009). Fokus ovog istraživanja je bliži drugom pitanju, te ćemo se u radu zadržati na Hofmanovoj teoriji o empatiji kao osnovu moralnosti i prosocijalnog delovanja. Hofman (Hoffman, 1984) zastupa stav da čovek poseduje urođenu sposobnost da doživljava emocionalno stanje drugih, što nastaje kao rezultat prirodne selekcije i usmerava pojedince na određenu reakciju. Altruistička motivacija povezuje emocionalni i kognitivni aspekt empatije i označava da sposobnost posrednog doživljavanja emocionalnog stanja druge osobe zavisi od sposobnosti osobe da zaključuje o afekivnom stanju drugih (Hofman \& Šešum, 2003).

Analizirajući empatiju kao osnovu altruističnog ponašanja, Batson (Batson, 1991) ističe značaj lične emocionalne uznemirenosti prilikom altruističnog delovanja i ukazuje da kada isključimo ličnu uznemirenost možemo govoriti o altruističnom ponašanju, jer u suprotnom motiv za altruističko ponašanje može biti nelagoda koju u pojedincu izaziva lična uznemirenost (egoistična motivacija). Sa druge strane, Hoffman (Hoffman, 1991) svoju teoriju zasniva na hipotezi da empatija može biti osnova altruističkog i prosocijalnog ponašanja izdvajajući empatičku uznemirenost. U svojim kasnijim radovima, nakon više od 30 godina istraživanja, Batson (Batson, 2010) je potvrdio značaj empatije kao preduslova altruističnog ponašanja izdvajajući altruističku i kolektivističku motivaciju nasuprot egoistične.

Motivaciona komponenta empatije se zasniva na razumevanju potreba i uznemirenosti druge osobe. Zahvalnost osobe kojoj je pružena pomoć je dovoljna povratna informacija, ali i motivacija za dalje pomažuće ponašanje što znači da empatija vodi ka pomaganju drugima i uzimanju u razmatranje njihovog pogleda. Cilj obrazovanja za podsticanje holističke empatije je razvoj veštine uzimanja u obzir perspektive drugih ljudi. Visok stepen empatije je korak ka pozitivnom ponašanju, vrednostima i emocijama. Empatična osoba polazi od zauzimanja perspektive drugog, razmišja o mogućim dobrim i lošim stvarima koje može da izazove kod druge osobe što je sprečava da se ponaša agresivno i destruktivno (Kalliopuska, 1992).

Važnost empatije za prosocijalno i altruističko ponašanje je osnova za pedagoško sagledavanje ove teme i ukazuje na potrebu proučavanja nastavnog procesa kao konteksta za realizovanje vaspitnih uticaja. Ono što potvrđuje iskazanu potrebu za vaspitnim delovanjem škole u ovoj oblasti je činjenica da je škola okruženje gde se dešavaju različiti oblici vršnjačkog nasilja, kao i da je potvrđena povezanost razvijenosti empatije sa ispoljavanjem vršnjačkog nasilja (Jolliffe \& Farrington, 2006) gde je utvrđeno da je niska emocionalna empatija značajno povezana sa učestalošću nasilja kod devojčica a niska uopštena empatija sa nasilnim ponašanjem dečaka. Vaspitna funkcija nastave u kontekstu podsticanja socioemocionalnog razvoja može se ogledati i u karakteristikama samih profesija koje impliciraju prisustvo empatičnih 
osećanja kao što su nastavničke profesije, profesije zdravstvenih radnika i ostale pomažuće profesije (Stanković Đorđević, 2007). Emocionalno vaspitanje treba da prožima nastavni proces od najranijeg uzrasta, počev od primarnog obrazovanja, ali i kasnije tokom srednje škole, pa i obrazovanja za profesiju kako bi se kod učenika podstakao razvoj empatičnih osećanja.

\section{Mogućnosti podsticanja empatije u nastavnom procesu}

Danas je primetan pojačan interes stručne javnosti za obrazovanje za demokratiju i kreiranje optimalnog okruženja u nastavi za pozitivno socijalno ponašanje i sprečavanje ispoljavanja nasilnih oblika ponašanja što nas navodi na pitanje koje su mogućnosti nastavnog procesa da odgovori na zahteve savremenog društva. Uvođenjem inovacija u nastavni proces, promenom tradicionalnih uloga nastavnika i učenika značajno se doprinelo kreiranju povoljnih okolnosti da se savremena nastava posveti i emocionalnom razvoju svojih učenika.

Socijalno i emocionalno vaspitanje obuhvata sve procese i metode koji se koriste za podsticanje i promovisanje socioemocionalnih kompetencija (Cohen, 2001). Razvijene socioemocionalne veštine i predispozije obezbeđuju osnovu za učestvovanje u demokratiji i poboljšanje kvaliteta života, te se predlaže da nastava obuhvata i socijalno, emocionalno i etičko vaspitanje (Cohen, 2006). O mogućnostima nastavnog procesa u ovom području vaspitnog delovanja govore i programi koji su usmereni na razvoj socioemocionalnih kompetencija poznatiji kao programi socioemocionalnog učenja (eng. social and emotional learning programmes-SEL) (Spinrad \& Eisenberg, 2009; Cohen, 2001). Ovi programi podrazumevaju različite pristupe i mogu biti usmereni na razvoj socijalnih veština, kognitivno-bihevioralni pristup, samoregulaciju, razvijanje veština rešavanja konflikta što ujedno predstavlja i osnovne forme emocionalnog vaspitanja. Sve pomenuto ukazuje na mogućnosti vaspitnog delovanja $u$ nastavi u cilju razvoja pozitivne emocionalne klime i emocionalnih kompetencija deca (Jevtić \& Petrović, 2016).

Pored termina socioemocionalno učenje, izdvaja se i termin socioemocionalno obrazovanje koji Rivs i Le Mare (Reeves \& Le Mare, 2017) smatraju prihvatljivijim jer je $u$ fokusu proces sticanja znanja i veština, gde se ističe proces realizovanja programa a ne pojedinci. Kvalitativno istraživanje koje su pomenuti autori realizovali ukazalo je na posvećenost nastavnika da neguju brižne odnose u svom odeljenju, i istakli su da je relacijska pedagogija dobra osnova za uspešno realizovanje socioemocionalnog vaspitanja jer saradnički odnosi na svim nivoima, razgovori o osećanjima i verovanjima omogućuju nastavnicima da bolje sagledaju svoje uloge i unaprede odnos sa učenicima.

Programi socioemocionalnog razvoja mogu se zasnivati i na korenima empatije (org. roots of empathy) (Gordon \& Green, 2008). Program se realizuje u jednom odeljenju koje posećuje beba sa svojim roditeljama u trajanju od devet meseci, što prati insktruktor koji redovno obilazi eksperimentalno odeljenje i realizuje lekcije. Lekcije sadržane u okviru ovog programa daju mogućnosti za učenje i diskutovanje 
o različitim aspektima empatije, zauzimanje tuđe perspektive i emocionalne osetljivosti. Primena ovog programa u realnom okruženju u svakodnevnoj praksi učionice je proučavana istraživanjem (Schonert-Reichl, Smith, Zaidman-Zait, \& Hertzman, 2012), koje je došlo do podataka da primena ovog programa, u odnosu na kontrolno odeljenje, nije dala značajne rezultata na razvoj empatije i zauzimanje perspektive druge osobe, ali je značajno uticala na razumevanje plača deteta, na razvoj prosocijalnog ponašanja i aktivnog delovanja što su značajni podaci za proširivanje efektivnosti primene ovih programa. Iako predstavljeni program pripada programima socioemocionalnog učenja, predstavljeni podaci ukazuju, da kada je reč o empatiji, bolje rezultate daju oni programi koji se zasnivaju na različitim aktivnostima učenika primenom scenarija kao što su igranje uloga, diskusije što ukazuje da su adekvatniji za primenu u realnom okruženju u cilju podsticanja empatije kod učenika osnovnoškolskog uzrasta.

Značaj vaspitanja za razvoj empatije prepoznao je i Hoffman i izdvojio nekoliko načina vaspitnog delovanja kao što su: omogućiti deci da dožive različite emocije, usmeriti dečiju pažnju na unutrašnja stanja drugih osoba; kreirati okolnosti za zauzimanje tuđe perspektive; verbalizovanje empatijskih osećanja a ne samo prosocijalno delovanje; zadovoljavanje emocionalnih potreba (Hofman \& Šešum, 2003; Jevtić, 2012). Modifikovanjem predstavljanih metoda moguće je vaspitno delovanje u okviru porodice i vaspitno-obrazovnih ustanova. Podsticanje dece da osete i dožive različite emocije, da dožive scenarija emocionalnih iskustava, otvoreno iskažu simpatiju i saosećanje predstavlja učenje veštine višestruke empatije. Neke od metoda koje se mogu koristiti u ovu svrhu su grupna diskusija o različitim moralnim dilemama, stimulisanje iskustva preuzimanja uloga, smanjenje agresivnosti dece kroz igre uloga kako bi doživeli tuđu poziciju i perspektivu (Jevtić, 2012). Primena ovih metoda je pokazala efekte na razvoj empatije kod učenika još prošlog veka izdvajajući igranje uloga, na šta je ukazao Hoffman (Hoffman, 1973) teorijskom analizom više istraživanja koji su ukazali na mogućnosti razvoja empatije i altruističnog ponašanja.

Važnost podsticanja empatije može se odgledati i kroz nedostatak empatije koji može dovesti do smanjenja pomagačkog ponašanja i do pronalaženja zadovoljstva u bolu i patnji drugih osoba. Pozitivni rezultati podsticanja empatije postižu se različitim aktivnostima igranja uloga, zauzimanja perspektive drugih, simulacije i pozitivne grupne interakcije što je znatno uticalo na povećanje empatije u grupi kao i izvan grupe (Bruneau \& Saxe, 2011).

O mogućnostima nastave u kontekstu podsticanja empatije govore i rezultati istraživanja koji potvrđuju: (1) značaj debate u nastavi za razvoj istorijske empatije (Jensen, 2008), gde je potvrđeno da su učenici bolje razumeli istorijski kontekst $i$ događaje iz prošlosti iz perspektive ljudi tog doba; (2) pozitivne rezultate primene empatičnih programa u nastavi za razvoj kritičke refleksije i akcije kod studenata socijalnog rada (Gair, 2011); (3) povoljan uticaj knjiga sa realističkim slikama na buđenje empatičnih osećanja kod dece uzrasta od 4 do 8 godina (Cress \& Holm, 1998). Primena debate u nastavi, promena pozicije učenika tokom učenja, kao i korišćenje realističnih slika mogu biti polazna osnova svim nastavnicima kako da 
organizuju nastavu u skladu sa karakteristikama nastavnih sadržaja, kako bi pored obrazovnih nastava ostvarila i vaspitne zadatke.

Predstavljeni stavovi autora ukazali su da najbolje rezultate na emocionalni razvoj učenika daju programi koji su obuhvatali različite saradničke aktivnosti u koje su učenici imali ulogu aktivnih učesnika i imali mogućnost da osete emocije i stave se u poziciju drugih, što je osnovna odlika radioničarskog načina rada. Sve aktivnosti koje su pokazale dobre rezultate u socioemocionalnom razvoju učenika, mogu biti samo jedan deo aktivnosti koje obuhvata radioničarski način rada. Uvažavajući sve pomenuto o mogućnostima vaspitnog delovanja nastave na socioemocionalni razvoj dece, radioničarski način rada je izdvojen kao savremeni vid realizovanja nastavnog procesa koji ima široke mogućnosti vaspitnog delovanja. Iz ovog razloga ćemo u daljem radu dati prikaz dosadašnjih istraživanja o ulozi i značaju pedagoških radionica u razvoju empatije.

\section{Radioničarski način rada kao osnova za podsticanje empatije u nastavi - osvrt na dosadašnja istraživanja}

Radioničarski način rada predstavlja vid saradničkog učenja koji karakteriše kružni raspored sedenja i kružna komunikacija, smenjivanjem različitih aktivnosti koje se mogu izvoditi unutar kruga. Svaka radionica se sastoji od početnih, glavnih i završnih aktivnosti. Početne i završne aktivnosti je poželjno realizovati u okviru kruga gde je omogućena ravnopravnost učenisnika, dok se glavne aktivnosti mogu realizovati u parovima ili manjih grupama (Buljubašić-Kuzmanović, 2006). Pedagoška radionica podrazumeva inovativni model koji uključuje angažovanje grupe ljudi koji zajedno stiču znanja, razmenjuju iskustva i pronalaze rešenja za određene probleme. Primenom ovog načina rada nastavnici imaju mogućnost da unapređuju svoju praksu i razvijaju kreativnost, dok učenici pored sticanja znanja razvijaju socijalne kompetencije (Ørngreen \& Levinsen, 2017).

Primena radioničarskog načina rada, i specifične uloge učesnika radionice $\mathrm{i}$ voditelja, su analizirane i sa aspekta različitih teorijskih konstrukata gde je potvrđena teorijska zasnovanost primene radionice $u$ nastavi sa aspekta humanističke psihologije, sociokuturalne teorije i teorije socijalnog konstruktivizma (Jacobs \& Seow, 2013). Isti autori potvrdili su da od podela uloga u radionici zavisi i emocionalni razvoj učenika i izdvojili dvanaest mogućih uloga voditelja što se može posmatrati kao potencijalne uloge nastavnika koji primenjuje radioničarski rad u svojoj nastavnoj praksi. Primenom različitih aktivnosti potrebno je kreirati osećaj emocionalne pripadnosti i bezbednosti, kao i motivisati učesnike u čemu se ogleda umešnost realizatora radionice još u fazi pripreme i organizacije.

Primena pedagoških radionica u nastavi doprinosi: boljem angažovanju učenika na času i manjim ispoljavanjem neprimerenog ponašanja (Evertson, 1989); povećanju osetljivosti učenika prema inkluzivnim osobama što je omogućilo studentima da kasnije i sami koriste radionice u radu u okviru inkluzivnog obrazovanja (Kirch, 2007); rešavanju emocionalnih i bihevioralnih simptoma i kod migrantske dece 
gde je eksperimentalna grupa pokazala manje internalizujuće i eksternalizujuće simptome (Rousseau, Drapeau, Lacroix, Bagilishya, \& Heusch, 2005). Predstavljena istraživanja su ukazala na mogućnosti primene radioničarskog rada u nastavi u smislu ostvarivanja pozitivnih efektata na različite aspekte socijalno-emocionalnog razvoja učenika. Iako predstavljeni podaci ne izdvajaju empatiju, što je tema našeg rada, aspekti emocionalnog razvoja učenika koji su obuhvaćeni daju osnovu za zaključivanje da se kod učenika povećava i nivo empatičnosti. Radioničarski metod je široko indikovan u nastavnom procesu, u svakom nastavnom predmetu što daje mogućnosti nastavnicima da maksimalno iskoriste vaspitni karakter nastavnih sadržaja i da utiču i na socioemocionalni razvoj svojih učenika.

Radioničarski način rada je primenjen u nastavi kao osnova za razvoj empatije još pre skoro pola veka, iako se radionica kao termin nije široko koristio, ali raznovrsnost $i$ tok primenjenih aktivnosti odgovara karakteristikama radioničarskog rada. Jedno od prvih istraživanja o različitim mogućnostima nastave za podsticanje empatije, bio je eksperiment (Kalliopuska, 1983), gde su učenici eksperimentalne grupe imali empatičnu kampanju u trajanju od nedelju dana. Nastavnici su imali važnu ulogu tokom realizovanja kampanje koja je podrazumevala različite aktivnosti: korišćenje empatijskih tema $u$ okviru nastavnih jedinica primenom različitih medija nakon čega učenici diskutuju; intenzivniji rad u okviru vannastavnih aktivnosti i školskih klubova; empatijske teme u okviru događaja u čije planiranje učestvuju učenici; realizovanje empatičnog dana ili nedelje gde bi se jedna tema obrađivala primenom različitih metoda; školski festival gde će se prezentovati rezultati rada učenika uz prisustvo roditelja. Dobijeni podaci su pokazali da se empatičnost učenika može povećati u nastavi kada je kampanja intenzivna i kada studenti imaju aktivno učešće u planiranju i realizovanju kampanje.

$\mathrm{Na}$ osnovu metaanalize identifikovano je 13 studija koje su istraživale podsticanje empatije kod studenata medicinskih nauka koristeći različite strategije. Analizom ovih primarnih studija došlo se do podataka da je moguće podsticati empatiju u nastavi, ali je ukazano i za dosta ograničenja analiziranih istraživanja. Izdvojeno je šest studija koje su potvrdile značaj radionica zasnovanih na komunikacijskim veštinama za podsticanje razvoja bihevijoralne empatije, što je ostvarilo značajan kvantitativan uticaj na učesnike istraživanja. Analiza kvalitativnih studija je pokazala da se može uticati na emocionalni i kognitivni aspekt empatije putem strategija zasnovanih na pozorištu i literaturi (Stepien \& Baernstein, 2006).

Radionice su primenjene i kao metod podsticanja empatija kod dizajnera, gde su primenjene četiri radionice koje su realizovali različiti timovi u različitim uslovima. Analizom razlike između timova potvrđen je značajan uticaj radionica koje se zasnivaju na stimulisanju dizajnera da se osvrnu na sopstvena iskustva kako bi dublje razumeli određenu temu (Visser \& Kouprie, 2008). Primena više radionica sa vatrogascima je pokazala značajne rezultate na razvoj empatije, gde su se izdvojile aktivnosti razvoj saradnje igranjem uloga i razumevanjem perspektive drugog (Dyrks et al., 2015). Utvrđena je pozitivna uloga radionice u promovisanju empatije kod studenata medicinskih nauka koriščenjem pozorišta i pripovedanja. Korišćene radionice su zasnovane na pozorišnim igrama kao što su igre posmatranja, 
zamrznute slike, vajarske aktivnosti, prenošenje karaktera u život, unošenje slika u život i na kraju životnih uloga (Marie, Trial, Piver, \& Schaff, 2012). Na sličnom uzorku, kod studenata medicinskih nauka potvrđen je i trajniji efekat radionica zasnovnih na pisanju pripovedaka, na razvoj sposobnosti brižnog posmatranja, sposobnost empatične brige za pacijente ili kolege, sposobnosti pisanja. Učesnici su istakli da su radionice u kojima su ranije učestvovali uticale na njihovu sposobnost uočavanja detalja, kao i dubljeg razumevanja iskustava drugih osoba (Lemay, Encandela, Sanders, \& Reisman, 2017).

Većina prikazanih istraživanja o primeni radioničarskog načina rada za podsticanje empatije je realizovana na uzorku studenata medicinskih nauka, što ukazuje na dvostruku vrednost utvrđenih pozitivnih rezultata. Sa jedne strane podaci govore o mogućnostima radioničarskog načina rada i na starijem uzrastu učesnika, a sa drugog aspekta na važnost razvijenosti empatije kod svih pomažućih profesija, pa i medicinskih radnika. Takođe, uzorak predstavljenih istraživanja ukazuje na studente što doprinosi kreiranju mišljenja da će primena radionica zasnovanih na igrama uloga i ličnom iskustvu dati još pozitivnije rezultate kod mlađih ispitanika, učenika srednjih i osnovnih škola.

S aspekta osnovnoškolskog uzrasta, može se izdvojiti istraživanje realizovano na uzorku učenika osnovnih škola (Jevtić, Đorić, \& Milošević, 2019) gde je korišćen radioničarski rad a rezultati su pokazali pozitivne efekte njihove primene na razvoj socijalnih kompetencija učenika. Pomenuto istraživanje je potvrdilo i uticaj primene radionice na razvoj empatije jer su učenici nakon realizovanja istraživanja pokazali da mogu da se stave u ulogu žrtve i da razumeju osećanja i ponašanja iz određene situacije. Radionica koja je značajno uticala na razvoj empatičnih osećanja kod učenika je igranje uloga, kada su učenici preuzimali ulogu žrtve i imali priliku da osete i iskuse osećanja diskriminisane osobe.

\section{Zaključna razmatranja}

Opšti zaključak do kojeg se došlo u ovom radu je da nastavni proces ima široke mogućnosti vaspitnog delovanja, kao i da realizovanje saradničkih aktivnosti podstiče razvoj socijalnih i emocionalnih kompetencija učenika. U podsticanju emocionalnog aspekta nastave presudna je uloga nastavnika, koji još u fazi planiranja i organizovanja svog rada treba da krene od emocija svojih učenika i kreira pozitivnu klimu u odeljenju. Pozitivni efekti na socioemocionalni razvoj učenika koji je utvrđen primenom različitih kooperativnih aktivnosti i strategije, kao što su igre uloga, dramske igre, simulacije, korišćenje literature, daju polaznu osnovu nastavnicima da u svojoj praksi primene neke od njih u zavisnosti od same prirode nastavnih sadržaja. Kada je reč o podsticanju empatije u nastavi, na osnovu analize prikazanih istraživanja može se zaključiti da najbolje rezultate daje korišćenje pedagoških radionica kao inovativnog modela nastave. Neke od aktivnosti koje su se pokazale kao najefikasnije, i koje treba obuhvatiti radionicom kako bi se kombinovanjem optimizovali njihovi pozitivni efekti su: kreiranje okolnosti da učesnici najpre osete svoje emocije, prepozavanje emocija 
koristeći literarne i dramske sadržaje, igranje uloga zasnovano na ličnom iskustvu, simulacije događaja sa izražavanjem osećanja. Za ostvarivanje trajnijh rezultata poželjno je realizovanje više radionica, što odgovara empatičnim programima u trajanju od nedelju dana ili mesec dana koji su se pokazali uspešnim. Definisani zaključci ukazuju na potrebu za osvešćivanjem nastavnika o važnosti emocionalnog vaspitanja, kao i o svim potencijalnim efektima koje emocionalna kompetentnost $\mathrm{i}$ emocionalni deficit imaju na ponašanje učenika, kako bi svoje delovanje usmerili na emocionalni razvoj učenika. Potencijalna opasnost može biti nedovoljna pripremljenost nastavnika za realizovanje inovativnih i kooperativnih modela učenja, što može biti i razlog nedovoljno realizovanih istraživanja na ovu temu na našim prostorima. U prilog ovome govore i rezultati sprovedenog istraživanja da je u cilju unapređivanja empatije u nastavi potrebno raditi na osnaživanju nastavnika i da „didaktično-metodičkim obrazovanjem i usavršavanjem kod nastavnika treba proširiti znanja o empatiji, njenoj ulozi i značaju i razvijati sposobnosti podsticanja empatije kod učenika" (Jovanović i Minić, 2019: 133).

Sa druge strane, predstavljeni podaci ukazuju na mogućnosti pedagoške radionice $\mathrm{i}$ mogu poslužiti kao motiv svim zaposlenima u vaspitno-obrazovnim ustanovama da inoviraju svoju nastavnu praksu, ali i istraživačima kao polazna osnova ili hipoteza na kojoj će zasnovati neko od budućih istraživanja.

\section{Literatura}

Batson, C. D. (1991). The altruism question: Toward a social-psychological answer. Retrieved from https://content.taylorfrancis.com/books/download?dac $=$ C2007-005289-3\&isbn=9781317785361\&format=googlePreviewPdf

Batson, C. D. (2009). These Things Called Empathy: Eight Related but Distinct Phenomena. In J. Decety \& W. Ickes (Eds.), The Social Neuroscience of Empathy (pp. 3-17). https://doi.org/10.7551/mitpress/9780262012973.003.0007

Batson, C. D. (2010). Empathy-induced altruistic motivation. In M. Mikulincer \& P. R. Shaver (Eds.), Prosocial motives, emotions, and behavior: The better angels of our nature (pp. 15-34). https://doi.org/10.1037/12061-001

Bruneau, M., \& Saxe, E. (2011). Us and Them: Intergroup Failures of Empathy. Current Directions in Psychological Science, 20(3), 149. https://doi. org/10.1177/0963721411408713

Buljubašić-Kuzmanović, V. (2006). Pedagoška radionica u funkciji aktivne nastave i učenja na uspjesima. Metodički Ogledi, 13(1), 123-136.

Cohen, J. (2001). Social and Emotional Education: Core concepts and practices. In J. Cohen (Ed.), Caring Classrooms/Intelligent Schools: The Social Emotional Education of Young Children. (pp. 3-29). New York.

Cohen, J. (2006). Academic Education : Creating a Climate for Learning, Participation in Democracy , and Well-Being. Harvard Educational Review, 76(2), 201-236. https:// doi.org/https://doi.org/10.17763/haer.76.2.j44854x1524644vn 
Cress, S. W., \& Holm, D. T. (1998). Developing empathy through children's literature. Retrieved from https://eric.ed.gov/?id=ED427316

Davis, M. H. (1983). Measuring individual differences in empathy: Evidence for a multidimensional approach. Journal of Personality and Social Psychology, 44(1), 113-126. Retrieved from https://psycnet.apa.org/record/1983-22418-001

Davis, M. H. (1996). Empathy: A social psychological approach. Retrieved from https:// content.taylorfrancis.com/books/download?dac $=$ C2017-0-76734-2\&isbn=97804294 93898\&format=googlePreviewPdf

Dyrks, T., Ramirez, L., Denef, S., Fit, F., Siegen, U., Penkert, B., \& Meyer, D. (2015). Designing for Firefighters — Building Empathy through Live Action Role. Proceedings of the 6th International ISCRAM Conference - Gothenburg, Sweden, May 2009, (January 2009).

Evertson, C. (1989). Improving Elementary Classroom Management: A School-Based Training Program for Beginning the. The Journal of Educational Research, 83(2), 82-90.

Gair, S. (2011). Creating spaces for critical reflection in social work education: Learning from a classroom-based empathy project. Reflective Practice, 12(6), 791-802. https:// doi.org/10.1080/14623943.2011.601099

Goleman, D. (2007). Socijalna inteligencija. Beograd: Geopoetika.

Gordon, M., \& Green, J. (2008). 34 Roots of Empathy: Changing the World, Child by Child. Education Canada, 48(2), 34-36. Retrieved from https://eric.ed.gov/?id=EJ790153

Hoffman, M. L. (1973). Empathy, role-taking, guilt, and development of altruistic motives. Retrieved from https://eric.ed.gov/?id=ED085109

Hoffman, M. L. (1984). Interaction of affect and cognition in empathy. In R. B. Z. Carroll E. Izard, Jerome Kagan (Ed.), Empathy and Its Development (pp. 103-131). Retrieved from https://books.google.rs/books?hl=sr\&lr=\&id=PVQ4AAAAIAAJ\&oi=fnd\&pg $=$ PR9\&dq=emphaty+hoffman\&ots $=$ Km3R3vgguy\&sig=V_0ZRHIBvDUeWq1O3i

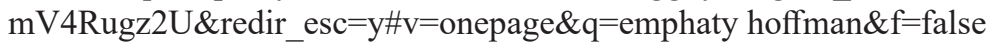

Hoffman, M. L. (1991). Is Empathy Altruistic ? Psychological Inquiry: An International Journal for the Advancement of Psychological Theory, 2(2), 131-133. https://doi. org/http://dx.doi.org/10.1207/s15327965pli0202_6

Hofman, M., \& Šešum, T. (2003). Empatija i moralni razvoj: značaj za brigu i pravdu. Beograd: Dereta.

Hogan, R. (1975). Empathy: A Conceptual Psychometric Analysis. The Counseling Psychologist, 5(2), 14-18. https://doi.org/10.1177/001100007500500204

Jacobs, G. M., \& Seow, P. (2013). The many co-operative roles available to workshop cofacilitators. In Journal of Co-operative Studies (Vol. 46).

Jensen, J. (2008). Developing Historical Empathy through Debate: An Action Research Study. Social Studies Research and Practice, 3(1), 55-67. Retrieved from www. socstrp.org

Jevtić, B. (2012). Pedagogija moralnosti. Niš: Filozofski fakultet.

Jevtić, B., Đorić, G., \& Milošević, D. (2019). Developing social competencies of pupils through workshops in physical education classes. Facta Universitatis, Series: Physical Education and Sport, 17(2), 259-275. https://doi.org/10.22190/FUPES190314025J 
Jevtić, B., \& Petrović, J. (2016). Emotional education as the basis for peer violence prevention. Didactica Slovenica- Pedagoška Obzorja, (31), 113-127.

Jolliffe, D., \& Farrington, D. P. (2006). Examining the Relationship Between Low Empathy and Bullying. AGGRESSIVE BEHAVIOR, 32, 540-550. https://doi.org/10.1002/ ab. 20154

Jovanović, M. \& Minić, V. (2019). Stavovi učenika srednjih škola u Kosovskoj Mitrovici i Nišu o empatičnosti nastavnika i načinima njenog ispoljavanja. Nauka bez granica II: Pristupi u obrazovanju, 119-137.

Kalliopuska, M. (1983). Empathy in school students. Retrieved from https://files.eric. ed.gov/fulltext/ED240423.pdf

Kalliopuska, M. (1992). HOLISTIC EMPATHY EDUCATION AMONG PRESCHOOL AND SCHOOL CHILDREN. International Scientific Conference on Comenius' Heritage and the Education of Man (Prague, Czechoslovalia, March 23-27, 1992), $1-20$.

Kirch, S. (2007). Inclusive Science Education: Classroom Teacher \& Science Educator Experiences in CLASS. FIRST INTERNATIONAL CONFERENCE ON TECHNOLOGY-BASED LEARNING WITH DISABILITY, 102-112. Retrieved from https://www.researchgate.net/publication/233810390

Lemay, M., Encandela, J., Sanders, L., \& Reisman, A. (2017). Writing Well: The LongTerm Effect on Empathy, Observation, and Physician Writing Through a Residency Writers' Workshop. In Journal of Graduate Medical Education. https://doi. org/10.4300/JGME-D-16-00366.1

Marie, J., Trial, J., Piver, D., \& Schaff, P. (2012). Using Theater to Increase Empathy Training in Medical Students. Journal for Learning through the Arts, 8(1). Retrieved from http://escholarship.org/uc/item/68x7949t

Mehrabian, A., \& Epstein, N. (1972). A measure of emotional empathy. Journal of Personality, 40(4), 525-543. https://doi.org/10.1111/j.1467-6494.1972.tb00078.x

Ørngreen, R., \& Levinsen, K. (2017). Workshops as a Research Methodology. The Electronic Journal of E-Learning, 15(1), 70-81.

Reeves, J., \& Le Mare, L. (2017). Supporting Teachers in Relational Pedagogy and Social Emotional Education: A Qualitative Exploration. The International Journal of Emotional Education, 9(1), 85-98. Retrieved from www.um.edu.mt/ijee

Rousseau, C., Drapeau, A., Lacroix, L., Bagilishya, D., \& Heusch, N. (2005). Evaluation of a classroom program of creative expression workshops for refugee and immigrant children. Journal of Child Psychology and Psychiatry, 46(2), 180-185. https://doi. org/10.1111/j.1469-7610.2004.00344.x

Schonert-Reichl, K. A., Smith, V., Zaidman-Zait, A., \& Hertzman, C. (2012). Promoting Children's Prosocial Behaviors in School: Impact of the "Roots of Empathy" Program on the Social and Emotional Competence of School-Aged Children. School Mental Health, 4(1), 1-21. https://doi.org/10.1007/s12310-011-9064-7

Spinrad, T., \& Eisenberg, N. (2009). Empathy, Prosocial Behavior, and Positive Development in Schools. In R. Gilman, E. S. Huebner, \& M. Furlong (Eds.), Handbook of Positive Psychology in Schools (pp. 119-129). Routledge. 
Stanković Đorđević, M. (2007). Empatičnost zdravstvenih i prosvetnih radnika. Ličnost $i$ Obrazovno-Vaspitni Rad Tematski Zbornik Radova, 47-60.

Stepien, K.A., \& Baernstein, A. (2006). Educating for empathy. Journal of General Internal Medicine, 21(5), 524-530. https://doi.org/10.1111/j.1525-1497.2006.00443.x

Visser, F. S., \& Kouprie, M. (2008). Stimulating empathy in ideation workshops. PDC, (10), 174-177. Retrieved from https://studiolab.io.tudelft.nl/manila/gems/ sleeswijkvisser/163.pdf

\title{
APPLING WORKSHOPS IN TEACHING IN THE CONTEXT OF DEVELOPING EMPATHY
}

\author{
Dragana Dimitrijević \\ University of Nis, Faculty of Philosophy, Department of Pedagogy (PhD student)
}

\begin{abstract}
Teaching as an interaction process, in which educational, functional, and upbringing tasks are intertwined, unites the intellectual, emotional, and active aspects of personality development. Oriented towards this concept, teaching must provide an opportunity for students to develop many organizational components through organizational activities, among which empathy has a significant place. As the ability to respect, understand and experience the feelings of others, empathy in teaching can be developed by those forms of teaching that are based on a cooperative relationship and full engagement of students in the process of acquiring knowledge and exchanging experiences. As the pedagogical workshop is an innovative form of teaching that is based on these features, the paper aims to review previous research in this area to indicate its role, opportunities, and importance in the process of developing empathy in students. The main conclusions are: the application of collaborative activities has positive effects on the emotional development of students and encourages empathy; the activity of participants based on personal experience presupposes more positive results on the students emotional development; creating circumstances for students to feel different emotions, role plays, simulations, the use of dramatic content were singled out as the most effective activities in teaching. The workshop provides an opportunity to combine different activities, and is recognized as the greatest potential that teachers can use in their practice to emphasize the emotional aspect of teaching and contribute to the development of empathy in students.
\end{abstract}

Keywords: socio-emotional learning, emotional education, workshop, the teaching process.

Citiranje članaka: Dimitrijević, D. (2020). Radioničarsi rad u nastavi u kontekstu podsticanja empatije. Godišnjak za pedagogiju, 5(1), 93-104. 